\title{
Effect of pasture species on milk yield and milk composition
}

\author{
ROBYN J. JOHNSON ${ }^{l}$ and N.A. THOMSON ${ }^{2}$ \\ ' Dairying Research Corporation, Taranaki Agricultural Research Station, PO Box 711, Normanby \\ 2 Dairying Research Corporation, PO Box 3123, Hamilton
}

\section{Abstract}

One IO-day experiment in autumn 1994 then four 10-day experiments throughout the 1994/95 lactation in a complete Latin square investigated the effect of pasture species on yield, composition and total colour of milk from dairy cows. Treatments were Grasslands Kopu white clover (Trifolium repens L.), Yatsyn- 1 perennial ryegrass (Lolium perenne L.), Grasslands Kahu timothy (Phfeum pratense L.) and Grasslands Kara cocksfoot (Dactylis glomerata L.) offered at similar allowances of green leaf. Cows grazing white clover produced higher $(\mathrm{P}<0.05)$ milk yields than cows grazing the other three pasture species, cows grazing timothy and ryegrass also producing more $(\mathrm{P}<0.05)$ than cocksfoot. Timothy produced milk with a higher $(\mathrm{P}<0.01)$ fat $\%$ than the other three species, whereas for cocksfoot protein $\%$ was lower $(\mathrm{P}<0.01)$. Grazing white clover increased $(\mathrm{P}<0.05)$ lactose \%. Milksolids production was highest from white clover. Within the grasses timothy gave the highest milksolids production. Pasture species did not affect total colour of milk. Ryegrass gave greater $(\mathrm{P}<0.05)$ liveweight gain than the other three pasture species in autumn 1994, but no significant differences in liveweight and condition score were measured in the trials run during the 1994/95 lactation. Pasture species fed at a similar allowance of green leaf had a significant effect on the yield and composition of milk, which suggests it may be possible to manipulate milk composition by altering pasture composition rather than by processing methods.

Keywords: Dactylis glomerata, lactose, Lolium perenne, milk composition, milk yield, milkfat, Phleumpratense, protein, Trifolium repens

\section{Introduction}

The dairy industry in New Zealand is pasture-based with a primary objective of producing at a low cost. Grazed pasture as a sole diet for dairy cows has been identified as a major limitation to New Zealand dairy production. The CANZ project (Graham et al. 1991) clearly demonstrated that the production potential of the New Zealand dairy cow was considerable-possibly $100 \%$ greater when fed a high energy mixed ration than on pasture alone. The major limitation appears to be that there is insufficient feed and the feed is of low quality, especially in summer (Mackle \& Bryant 1994). This, however, could change with the manipulation of pasture species to produce a higher yield of quality pasture over summer. For example, it is well documented that the intake and performance of dairy cows grazing white clover is greater than for grasses (Thomson \& Raymond 1970).

White clover has a high nutritive value compared with grasses owing to lower levels of structural carbohydrate (Ulyatt 1970), higher digestible protein and faster rate ofpassage (Rattray \& Joyce 1974). Studies at the Ellinbank Dairy Research centre in Victoria, Australia, clearly demonstrated the benefits of white clover to dairy production, especially over the later stages of lactation in a spring calving herd (Rogers et al. 1982). A short-term grazing study at the Taranaki Agricultural Research Station also showed significant effects of pasture species on milk composition with no effect on milksolids production (Thomson \& Barnes 1990). Results from these trials indicate that pasture species influence milk composition. The effect of different pasture species on yield, composition and total colour of milk were investigated further at the Taranaki Agricultural Research Station.

\section{Method}

Five 1 -ha paddocks each divided into five 0.2-ha strips werc established in Grasslands Kopu white clover (Trifolium repens L.), Yatsyn-1 perennial ryegrass (Lolium perenne L.), Grasslands Kara cocksfoot (Dactylis glomerata L.), Grasslands Kahu timothy (Phleum pratense L.) and Necton sulla (Hedysarum coronarium) in spring 1993. Sowing rates were $15 \mathrm{~kg} /$ ha, $8 \mathrm{~kg} / \mathrm{ha}, 6 \mathrm{~kg} / \mathrm{ha}, 10 \mathrm{~kg} / \mathrm{ha}$ and $8 \mathrm{~kg} / \mathrm{ha}$ respectively. The establishment of sulla failed on 3 occasions and the treatment was discontinued.

In autumn 1994, one 1 O-day trial was conducted as a preliminary to a full programme in the 1994/95 season. 


\section{Trial 1: Autumn 1994}

The trial was run from $1 / 3 / 94$ to $10 / 3 / 94$. Eight Friesian $\mathrm{x}$ Jersey cross dairy cows were balanced for current milk yield, milksolids yield, fat, protein and lactose content, liveweight, condition score, age, breed and lifetime BI, then allocated across the four treatment groups. Average liveweight of the cows was $440 \mathrm{~kg}$.

\section{Pasture measurements}

Cows spent 2 days in each paddock and were offered a similar allowance (30-35 kg DM/cow/day). Herbage mass of each species was assessed 2 days before grazing by taking 50 rising plate meter readings on each 0.2-ha strip. The mean and standard deviation (SD) were calculated, then, using the rising plate meter to determine $\mathrm{kg} \mathrm{DM} / \mathrm{ha}$, three $0.2 \mathrm{~m}^{2}$ quadrats were selected and cut to ground level, one at the mean and one at each SD. Pasture was then washed and dried to calculate average herbage mass. Pasture allowance offered was based on the species with the lowest mass. If the pasture mass was higher on any one treatment, the area grazed on that treatment was reduced to ensure a similar allowance. The same procedure was followed before and after the grazing of each paddock. All cows were also fed $3 \mathrm{~kg} \mathrm{DM} /$ cow/day as silage, to minimise the possibility of hydrogen cyanide $(\mathrm{HCN})$ poisoning on white clover. As a further precaution, all cows were drenched after the morning milking with anti-bloat drench.

A sample was collected (cut to grazing height) from each pasture species before grazing. The sample was subsampled for analysis of botanical composition (sown species, weed and dead matter), dry matter $\%$, in vitro digestibility, neutral detergent fibre (NDF) and total nitrogen.

\section{Animal measurements}

Animal liveweight and condition score were measured before the morning milking at the start of the trial and again at the same time 2 days after the completion of the trial, The delay was a precaution to allow the trial cows to stabilise gut fill while under common grazing.

Milk yield and composition were measured on the day before the start of the trial from a p.m./a.m. sampling procedure and the results from this were used to form a covariate. Milk yield and composition (fat, protein and lactose concentrations) were measured on days 6,8 , and 10 from a p.m./a.m. sampling procedure. From the a.m. sampling on days 8 and 10 an additional milk sample was taken with no preservative added, frozen and later analysed for total colour. Milk composition was analysed at the DRC milk laboratory using the milkoscan. Statistical analysis was done by analysis of variance using a covariate.

\section{Trial 2: 1994195 lactation}

Four 10-day experimental periods starting 21/10/94, $6 / 12 / 94,16 / 1 / 95$ and $7 / 3 / 95$ were run to give a complete Latin square design. Thirty-two dairy cows, balanced for the same variables as for trial 1 , were allocated across the four treatments. Each group grazed each pasture species; Kopu white clover, Yatsyn-1 perennial ryegrass, Kara cocksfoot and Kahu timothy according to the preset design, giving 32 individual cow measures per treatment over the season. In the periods beginning $31 / 10 / 94$ and $6 / 12 / 94,2$ cows were added to each treatment group to utilise the surplus pasture. These two cows were removed in the periods beginning 16/1/96 and $7 / 3 / 95$ owing to the decline in the availability of pasture.

Animal measurements were the same as those in trial 1, but the pasture measurements differed.

\section{Pasture measurements}

Herbage mass was assessed on each 0.2 -ha block the day before grazing by harvesting six 5-m strips with a rotary mower, to a height of $6 \mathrm{~cm}$ on the ryegrass and cocksfoot, and $4 \mathrm{~cm}$ on the timothy and white clover. These heights were determined by a sward profile study conducted on each species in September 1994 (Johnson unpublished). The morphology of each species differs and in an attempt to offer the cow a similar allowance of green leaf material the two heights were selected. If the herbage mass above the respective grazing heights was higher on any one treatment, grazing area was reduced to maintain a constant allowance of green leaf material. Post-grazing measurements were taken to the same heights as the pre-grazing measurements using a rotary mower.

Owing to suspected $\mathrm{HCN}$ poisoning of the cows grazing white clover on day 2 of the first 10-day experimental period, the clover cows were removed from the clover and grazed perennial ryegrass pasture for an 8-hour period. The cows were returned to the treatment and all treatments were supplemented with 3 $\mathrm{kg} \mathrm{DM} /$ cow/day of pasture silage to dilute a possible cyanide effect. In the next three IO-day experimental periods starting 6/12/94, 16/1/95 and 7/3/95, the cows grazing white clover were allocated $3 \mathrm{~kg} D M /$ cow/day less clover. The $3 \mathrm{~kg} \mathrm{DM} / \mathrm{cow} /$ day deficit was made up by offering a strip of perennial ryegrass pasture for a I-hour period after the morning milking. To allocate this pasture, pasture was assessed using a rising plate meter and herbage mass calculated using the TARS equation relative to the period $\left(\mathrm{MR}^{*} 114+1260\right.$ in November and December then MR* $182+1419$ in January and March; McCallum unpublished). To achieve the 3 $\mathrm{kg} \mathrm{DM} /$ cow/day intake of ryegrass, a herbage allowance of $7 \mathrm{~kg} \mathrm{DM} /$ cow/day was offered for the 1-hour period. 


\section{Results}

\section{Trial 1: Autumn 1994}

\section{Pasture measurements}

The available herbage mass before grazing was significantly higher on ryegrass and clover than on timothy and cocksfoot, resulting in reduced grazing area for these species. However, after adjustment of the grazeable area no significant differences in allowance or rate of DM disappearance in $\mathrm{kg} \mathrm{DM} /$ cow/day were recorded (Table 1).

The perennial ryegrass pasture had the highest content of sown species (95\%), significantly higher $(\mathrm{P}<0.05)$ than either cocksfoot $(76 \%)$ or clover $(77 \%)$, but similar to timothy (93\%). The remainder of the pasture was made up of weed, predominantly dock and dead matter.

Cocksfoot pasture had the lowest digestibility $(\mathrm{P}<0.01)$ (Table 1).

\section{Milk yield and composition}

Cows grazing white clover produced higher milk yields $(\mathrm{P}<0.05)$ than cows grazing ryegrass or cocksfoot (Table 2). Cows grazing timothy produced more $(\mathrm{P}<0.01)$ than cows grazing cocksfoot and ryegrass.

Cows grazing perennial ryegrass yielded higher $(\mathrm{P}<0.01)$ fat \% than cows grazing either cocksfoot or white clover. Timothy increased $(\mathrm{P}<0.05)$ fat $\%$ compared with cocksfoot only. A similar trend occurred in protein $\%$, with increased $(\mathrm{P}<0.01)$ protein $\%$ from cows grazing perennial ryegrass. Lowest protein $\%$ was in milk from cows grazing cocksfoot, resulting in lower $(\mathrm{P}<0.01)$ milksolids production/cow/day. Milksolids production was highest in cows grazing either white clover or timothy.

Conversely, cows grazing perennial ryegrass had lower lactose \% than cows on timothy, but the difference was not significant on white clover or cocksfoot.

\section{Total colour}

Differences in total colour of milk from the morning sampling were not significant. Total colour ranged from $5.5 \mu \mathrm{g} / \mathrm{g}$ of fat from grazing white clover compared with $6.1 \mu \mathrm{g} / \mathrm{g}$ of fat for ryegrass.

\section{Liveweight and condition score}

Cows grazing perennial ryegrass and white clover gained liveweight (Table 2), the gain being greater $(\mathrm{P}>0.05)$ on ryegrass than on cocksfoot or timothy (Table 3 ). Condition score did not change.

\section{Trial 2: 1994/95 lactation}

\section{Cow health}

After grazing white clover pasture (86\% clover) for 2 days starting 1 November 1994,3 cows of the 10 on the clover treatment came in for milking staggering and frothing at the mouth. Suspected HCN poisoning was diagonised by a veterinarian. Two of the cows recovered after a change of diet, but the third cow died overnight. An autopsy was inconclusive.

Table 1 Autumn 1994 - pasture measurements, Trial 1

\begin{tabular}{|c|c|c|c|c|c|c|}
\hline & $\begin{array}{c}\text { Total nitrogen } \\
(\%)\end{array}$ & $\begin{array}{c}\text { In vitro } \\
\text { Digestibility } \\
(\%)\end{array}$ & $\begin{array}{l}\text { Pre-grazing } \\
\text { herbage mass } \\
\text { (kg DM/ha) }\end{array}$ & $\begin{array}{c}\text { Grazing area } \\
\text { (ha) }\end{array}$ & $\begin{array}{c}\text { Allowance } \\
\text { (kg/cow/day) }\end{array}$ & $\begin{array}{l}\text { Dry matter } \\
\text { disappearance } \\
(\mathrm{kg} / \mathrm{cow} / \mathrm{day})\end{array}$ \\
\hline Ryegrass & 4.02 & 72.1 & 3393 & 0.13 & 31.0 & 13.3 \\
\hline Cocksfoot & 4.03 & 59.2 & 2877 & 0.19 & 38.7 & 14.2 \\
\hline Timothy & 4.24 & 70.4 & 2706 & 0.19 & 36.1 & 13.8 \\
\hline $\begin{array}{l}\text { Clover } \\
\text { Significance }\end{array}$ & $\begin{array}{c}4.26 \\
\text { NS }\end{array}$ & $\begin{array}{c}68.8 \\
\#\end{array}$ & 3500 & 0.15 & $\begin{array}{l}35.8 \\
? .\end{array}$ & 12.8 \\
\hline LSD $\quad 0.05$ & & 3.6 & 539 & & & \\
\hline LSD 0.01 & & 5.1 & & & & \\
\hline
\end{tabular}

Table 2 Autumn 1994 animal measurements, Trial 1

\begin{tabular}{|c|c|c|c|c|c|c|c|}
\hline & $\begin{array}{l}\text { Milk yield } \\
\text { (1/cow/day) }\end{array}$ & $\begin{array}{l}\text { Fat } \\
(\%)\end{array}$ & $\begin{array}{l}\text { Protein } \\
(\%)\end{array}$ & $\begin{array}{l}\text { Lactose } \\
(\%)\end{array}$ & $\begin{array}{c}\text { Milksolids } \\
\text { (kg/cow/day) }\end{array}$ & $\begin{array}{l}\text { Liveweight } \\
\text { change (kg) }\end{array}$ & $\begin{array}{l}\text { Condition } \\
\text { score change }\end{array}$ \\
\hline Ryegrass & 11.4 & 5.75 & 3.79 & 4.62 & 1.09 & +12 & +0.1 \\
\hline Cocksfoot & 9.7 & 5.24 & 3.55 & 4.58 & 0.85 & +1 & 0 \\
\hline Timothy & 12.9 & 5.68 & 3.75 & 4.57 & 1.19 & +1 & to.1 \\
\hline Clover & 13.5 & 5.28 & 3.60 & 4.67 & 1.19 & +7 & to. 2 \\
\hline Significance & * & & & $*$ & & 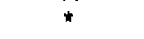 & NS \\
\hline LSD $\quad 0.05$ & 1.2 & 0.23 & 0.12 & 0.07 & 0.11 & 8.9 & \\
\hline LSD $\quad 0.01$ & 1.6 & 0.32 & 0.16 & 0.09 & 0.14 & & \\
\hline
\end{tabular}


Table 3 1994/95 lactation-pasture measurements, Trial 2

\begin{tabular}{|c|c|c|c|c|c|c|}
\hline & $\begin{array}{l}\text { Grazing area } \\
\text { (ha) }\end{array}$ & $\begin{array}{c}\text { Allowance' } \\
\text { (kg DM/cow/day) }\end{array}$ & $\begin{array}{l}\text { DM disappearance } \\
\text { (kg DM/cow/day) }\end{array}$ & $\begin{array}{c}\text { Sown species } \\
\text { start } \\
(\%)\end{array}$ & Sown & $\begin{array}{l}\text { species } \\
\text { end } \\
\text { (\%) } \\
\end{array}$ \\
\hline Ryegrass & 0.17 & 14.1 & 11.2 & 96 & & 88 \\
\hline Cocksfoot & 0.15 & 14.2 & 12.0 & 88 & & 88 \\
\hline Timothy & 0.17 & 15.2 & 11.9 & 89 & & 78 \\
\hline Clover & 0.13 & $15.5^{\star \star}$ & $13.1^{* \star *}$ & 86 & & 77 \\
\hline Significance & NS & NS & NS & * & & \\
\hline $\begin{array}{ll}\text { LSD } & 0.05 \\
\text { LSD } & 0.01\end{array}$ & & & & $\begin{array}{c}8 \\
10\end{array}$ & & \\
\hline
\end{tabular}

- above selected heights

* includes the $3 \mathrm{~kg} \mathrm{DM} /$ Cow/day of perennial ryegrass

Table 4 1994/95 lactation - animal measurements, Trial 2

\begin{tabular}{|c|c|c|c|c|c|c|c|}
\hline & $\begin{array}{l}\text { Milk yield } \\
\text { (//cow/day) }\end{array}$ & $\begin{array}{l}\text { Fat } \\
(\%)\end{array}$ & $\begin{array}{l}\text { Protein } \\
(\%)\end{array}$ & $\begin{array}{l}\text { Lactose } \\
(\%)\end{array}$ & $\begin{array}{c}\text { Milksolids } \\
\text { (kg/cow/day) }\end{array}$ & $\begin{array}{l}\text { Liveweight } \\
\text { change }(\mathrm{kg})\end{array}$ & $\begin{array}{l}\text { Condition } \\
\text { score change }\end{array}$ \\
\hline Ryegrass & 14.6 & 5.26 & 3.75 & 4.69 & 1.26 & +3.3 & +0.06 \\
\hline Cocksfoot & 13.3 & 5.31 & 3.60 & 4.69 & 1.14 & +5.3 & +0.11 \\
\hline Timothy & 14.9 & 5.64 & 3.76 & 4.60 & 1.36 & +4.5 & +0.04 \\
\hline Clover & 16.4 & 5.29 & 3.72 & 4.73 & 1.40 & +3.5 & +0.01 \\
\hline $\begin{array}{l}\text { Significance } \\
\text { LSD } 0.05\end{array}$ & 0.95 & $\stackrel{* *}{*}$ & 0.04 & 0.03 & $7.1 \%$ & NS & NS \\
\hline LSD $\quad 0.01$ & & 0.08 & 0.06 & 0.05 & & & \\
\hline
\end{tabular}

\section{Pasture measurements}

Neither allowance of pasture on offer nor rate of DM disappearance differed at any of the individual IO-day experimental periods (Table 3). The reduced grazing area for the clover cows resulted from the allocation of $3 \mathrm{~kg}$ DM of perennial ryegrass/cow/day.

Pasture composition between the different pasture species did not differ at the start of the trial in November 1994. By the end of the trial in March 1995 the sown species content of all species had declined (Table 3). The ryegrass and cocksfoot had a higher $(\mathrm{P}<0.01)$ sown species content than the timothy and white clover. The remainder of the sward comprised predominantly weeds, particularly dock.

\section{Milk yield and composition}

Cows grazing white clover had higher $(\mathrm{P}<0.05)$ milk yield than cows grazing grasses (Table 4). Cows grazing ryegrass and timothy had higher $(\mathrm{P}<0.05)$ milk yield than those grazing cocksfoot.

Cows grazing pure swards of timothy had significantly greater $(\mathrm{P}<0.01)$ fat $\%$ than cows grazing all other species. The other species had no effect on fat $\%$.

Protein \% was depressed $(\mathrm{P}>0.05)$ by grazing cocksfoot and lactose \% increased $(\mathrm{P}>0.05)$ by grazing white clover compared with the other three species. Grazing of timothy. depressed $(\mathrm{P}<0.01)$ lactose \% compared with ryegrass or cocksfoot.

\section{Total colour}

Pasture species had no effect.

\section{Liveweight and condition score}

Neither animal liveweight nor condition score change were affected over the treatment period (Table 4).

\section{Discussion}

Kopu white clover has one of the lower HCN levels (Crush \& Caradus 1995) of the agronomically successful cultivars used in New Zealand. The inclusion of perennial ryegrass or silage as approximately one sixth of the diet eliminated the incidence of health problems in cows grazing pure white clover.

The average milk yield recorded over the two trials from cows grazing white clover was $12.6 \%, 7.1 \%$ and $28.0 \%$ greater than that recorded on ryegrass, timothy and cocksfoot respectively. This relative increase in milk yield was less than that recorded at Ellinbank Research Institute, Victoria, Australia where increases under ad lib. feeding of $25 \%$ were obtained from grazing white clover compared with perennial ryegrass (Rogers et al. 1982). No significant differences in the digestibility of the ryegrass and white clover pastures were measured in autumn 1994 in contrast to a $6 \%$ difference in digestibility $\%$ of white clover compared with perennial ryegrass in the Ellinbank trials. Pasture samples collected 
during the 1994/95 series for in vitro digestibility, total nitrogen and neutral detergent fibre are yet to be processed.

In the autumn 1994 trial, fat and protein concentrations of cows grazing ryegrass and white clover were significantly different. However, this was not repeated in any of the four trials conducted throughout the $1994 / 95$ series, indicating variation between years in the effects observed. In all trial periods during the 1994/95 lactation, lactose \% from grazing white clover was significantly higher than from perennial ryegrass.

Although fat and protein concentrations differed between the two trials, both trials showed that milksolids production was highest on white clover.

Langer (1990) reported timothy to be a high quality grass; this was confirmed in these trials. Over the two trials the average milk production from timothy was $5.8 \%$ greater than from ryegrass and $20 \%$ greater than from cocksfoot. Stevens et al. (1993) showed similar advantages for timothy with sheep and goat liveweight gains. Timothy as a sole diet to dairy cows has potential for increasing milk yields and increasing fat and lactose $\%$.

Compared with white clover, ryegrass or timothy, cocksfoot depressed milk yield and protein \%. A similar result was obtained in past trial work at TARS when cocksfoot produced lower milksolids production than ryegrass at a similar pasture allowance (Thomson unpublished). The most highly valued component of milk, protein, was reduced $(\mathrm{P}<0.01)$ under cocksfoot grazing compared with ryegrass or white clover. In autumn 1994 the digestibility of the cocksfoot pasture was lower than that of the perennial ryegrass $(72 \%$ vs $59 \%)$. The extent of this difference would account for the large production differences recorded in dairy performance. Most other work on the value of cocksfoot for animal production has been done under either sheep or goat grazing, and work by Stevens et al. (1992) suggests no differences in animal performance between perennial ryegrass and cocksfoot.

Milksolids production was greatest when grazing white clover, indicating the importance of white clover in dairy pastures. Of the grasses, timothy gave the highest milksolids production, indicating possible benefits from using timothy in dairy pastures.

\section{Conclusions}

Pasture species significantly affected both milk yield and milk composition. White clover increased milksolids production compared with all grass species. Timothy resulted in higher production than either ryegrass or cocksfoot. Changes in milk composition were:
- Timothy feeding significantly increased fat $\%$.

- Cocksfoot feeding significantly depressed protein $\%$.

- White clover feeding significantly increased lactose $\%$.

\section{ACKNOWLEDGEMENTS}

The authors gratefully acknowledge Rhonda Sutherland for statistical analysis, Margaret Bryant and staff at the DRC milk laboratory for milk analysis, Gary Engelen, Mark Austen and Colm Tierney for assistance in management of the experimental herds and Tracee Judd, Chris Mudford and Andrea Pearson for technical assistance.

\section{REFERENCES}

Crush, J.R; Caradus, J.R. 1995. Cyanogenesis levels and iodine concentration in white clover (Trifolium repens L.) cultivars. New Zealand journal of agricultural research 38: IN PRESS

Graham, N.J; Burnside, E.B; Gibson, J.P; Rapitta, A.E; McBride, B.W. 1991. Comparison of daughters of Canadian and New Zealand Holstein sires for first lactation efficiency of production in relation to body size and condition. Canz journal of animal science 71: $293-300$

Langer, R.H.M. 1990. Pasture Plants. Chapter 2 In Pastures: their ecology and management. Langer, R.H.M. ed. Auckland, Oxford University Press.

Mackle, T.M; Bryant, A.M. 1994. How good is pasture. Proceedings of Ruakura Farmers Conference 46. 64-69.

Rattray, P.V; Joyce, J.P. 1974. Nutritive value of white clover and perennial ryegrass. IV Utilisation of Dietary Energy. New Zealand journal of agricultural research 17: 40 l-406.

Rogers, G.L; Porter, R.H.D; Robinson, J; 1982. Comparison of perennial ryegrass and white clover for milk production. Proceedings Conference "Dairy Production from Pasture ", pp. 2 13-2 14.

Stevens, D.R; Baxter, G.S; Casey, M.J; Miller, K.B; Lucas, R.J. 1992. A comparison of six grasses for animal production. Proceedings of the New Zealand Grassland Association 54: 147-I 50.

Stevens, D.R; Casey, M.J; Turner, J.D; Baxter, G.S; Miller, K.B; 1993. Grasslands Kahu timothy; quality pasture for animal performance. Proceeding New Zealand Grassland Association 55: 127-1 32.

Thomson, N.A; Barnes, M.L. 1990. Alternative pastures to old ryegrass/white clover for dairying. Dairy Farming Annual 42: 122-1 24.

Thomson, D.J; Raymond, W.F. 1970. White clover in animal production -nutritional factors. Occasional 